\title{
The Comparative Analysis of the Islamic and Conventional Bank System in Turkey
}

\author{
Vivien Pavelka (Kaposvár University, Hungary) \\ Dr. Gyöngyi Bánkuti (Kaposvár University, Hungary) \\ Dr. Jozsef Varga (Kaposvar University, Hungary)
}

\begin{abstract}
The aim of our study is the comparative analysis of the Islamic and conventional bank systems in Turkey focusing on the years of the last financial crisis. The financial crisis of 2008 shocked the world and impeached the confidence in the conventional bank systems. It drew the attention to the alternative financial forms like Islamic banking. The best known specialty of the Islamic bank system is the prohibition of interests and speculative transactions. The question is: are Islamic banks more crisis-resistant than the conventional banks? Are they really more stable? We would like to get answers for these questions through analyzing the four Islamic banks and four conventional banks with the same size in Turkey. We set up three hypothesizes:

1. The profitability of the Islamic banks was higher during the crisis than the profitability of the conventional banks.

2. The liquidity of the Islamic banks was higher during the crisis than the liquidity of the conventional banks.

3. The leverage ratio of the Islamic banks was higher during the crisis than the leverage ratio of the conventional banks.
\end{abstract}

The time horizon of the research is from 2007 to 2013 and we get the data from the annual reports of the banks.

\section{The Islamic Banking System in General}

French and English investments helped the Islamic banking system to be born during the colonization. The first banks were parts of the colonial banking system and the first banks were the Ottoman Bank and the Bank of Persia. The Ottoman Bank was founded in Turkey by French and English investors, while the Bank of Persia was founded in Iran by English investors. That time the Muslims wanted to found a bank on their own, but they faced some difficulties, mainly the technique of interest, that is against the Sharia law. The solution was the Islamic banks let the European financial experts take part in the bank system. That was the way how Islamic banks has born (YousefiKóbori, 2013).

The Islamic bank system is based on the five principles of Saria. These principles are obligatory for all of the Islamic financial institutions:

1. The prohibition of interests.

2. Paying zakat. Zakat means solidarity tax. As banks have high incomes, that's why they have to pay solidarity tax (Varga, 2013). Prophet Muhammad introduced this taxi in order to maintain the community and decrease the wealth inequalities. Who has significant property has to pay this tax. The amount of the tax is $2,5 \%$ of the property (Yousefi-Kóbor, 2013). The zakat should be paid in every 355 days, which means one lunar year (Falus, 2014).

3. Transactions against the principles of Islam is forbidden. That's why Islamic banks can't finance alcohol, weapons or gambling (Pálfi, 2010).

4. Islamic banks have to avoid transactions with high risks such as speculative transactions (Pálfi, 2010). Every transaction has to be evaluated individually in order to avoid high risk taking. We can't find standardized transactions in the Islamic banking system. There is a special relationship between the bank and the customer, we call it profit and loss share (Balázs et al, 2014).

5. The last principle is profit and loss sharing. The bank and the customer determine in the contract the amount of profit and loss that they will bear (Pálfi, 2010).

\section{The Turkish Bank System}

The Turkish banking system can be divided into three parts: commercial banks, investment banks and Islamic banks (Tálos, 2015). The Islamic banks had the 7\% of the assets of the Turkish banking sector in 2012 (ey.com, 2014). The Turkish Islamic banks had stable growth path since 2000 , when they had only the $2 \%$ of the Turkish bank sector. The whole Islamic banking capital reached the 60 trillion dollar worldwide which is a significant result. The Islamic banks had 966 branches in Turkey in 2014 which is higher by 40\% than in 2011 (herdem.av.tr, 2014).

Recent surveys show that Islamic financial sector will have a bright future, because:

- increasing number of Muslim customers,

- the Turkish state supports the sector, 
- increasing number of small and medium-sized enterprises who are interested in Islamic finance,

- a fifth Islamic bank, Ziraat Bankasi was opened in 2015 and they are planning to open another one (Turkey Islamic Finance Report, 2014).

\section{The Comparative Analysis of the Islamic and Conventional Bank System in Turkey}

We would like to prove that the Islamic banks are more crisis-resistant than the conventional banks in Turkey. We use ratios suitable for examining this, such as profitability ratios (Return on assets -ROA, Return on equityROE), liquidity ratio (IAR) and leverage ratio. On the first diagram we signed the Islamic banks with green - as green is the colour of Islam. We constructed the average of the bank sectors by weighting the total amounts of the balance sheets. This way we got a more detailed picture. The calculation based on the annual reports of the banks. The time horizon is 2007-2014.

\subsection{The Analysis of Profitability}

The profitability shows how effectively the bank operates. ROE calculates how many dollars of profit a company generates with each dollar of shareholders' equity. The healthy percentage of ROE is $10-12 \%$.

\section{The ROE of the two banking systems}

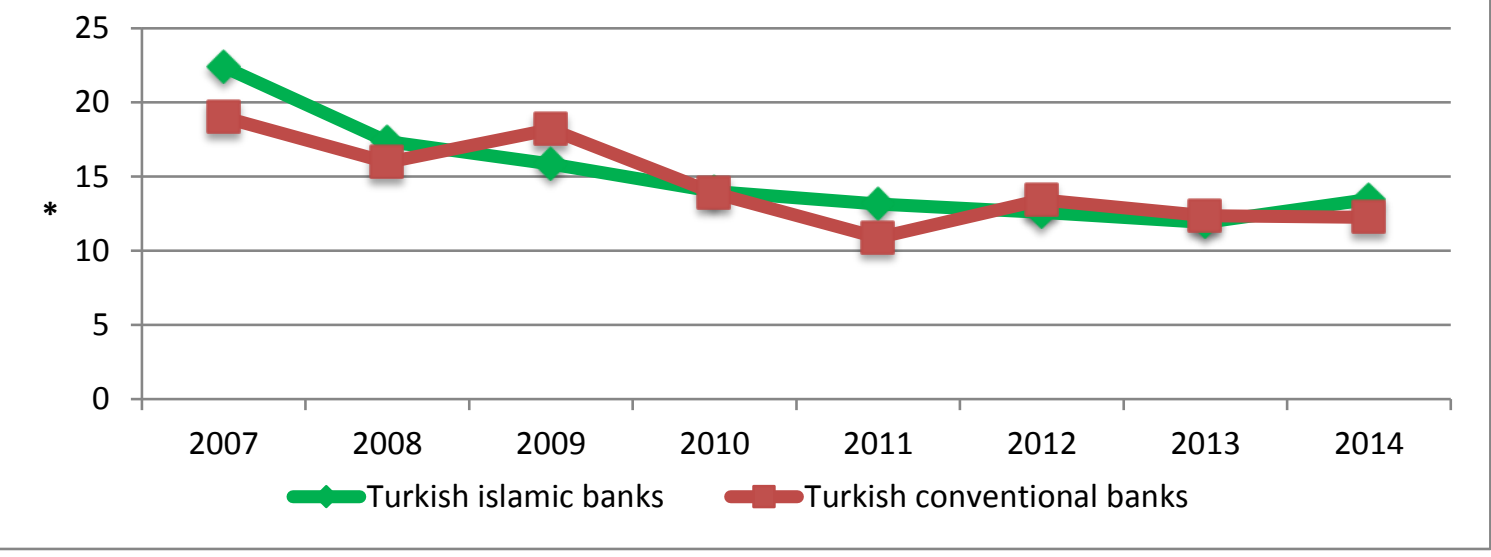

Figure 1: Average ROE of the Two Banking Systems Source: Own Calculation Based on the Annual Reports of the Banks

We can see that ROE of the conventional banks started to decrease in the financial crisis, while there is no similar decrease in the Islamic banking sector. There is a decrease by $12 \%$ during 5 years in the conventional banking sector. We can see a decrease of $9 \%$ during 6 years in the Islamic banking system. But on the other hand, both sector reached the healthy limit of $10 \%$.

The ROA ratio measures how efficiently a company can manage its assets to produce profits during a period. The healthy limit of ROA is between 1 and 2 (Tálos, 2015).

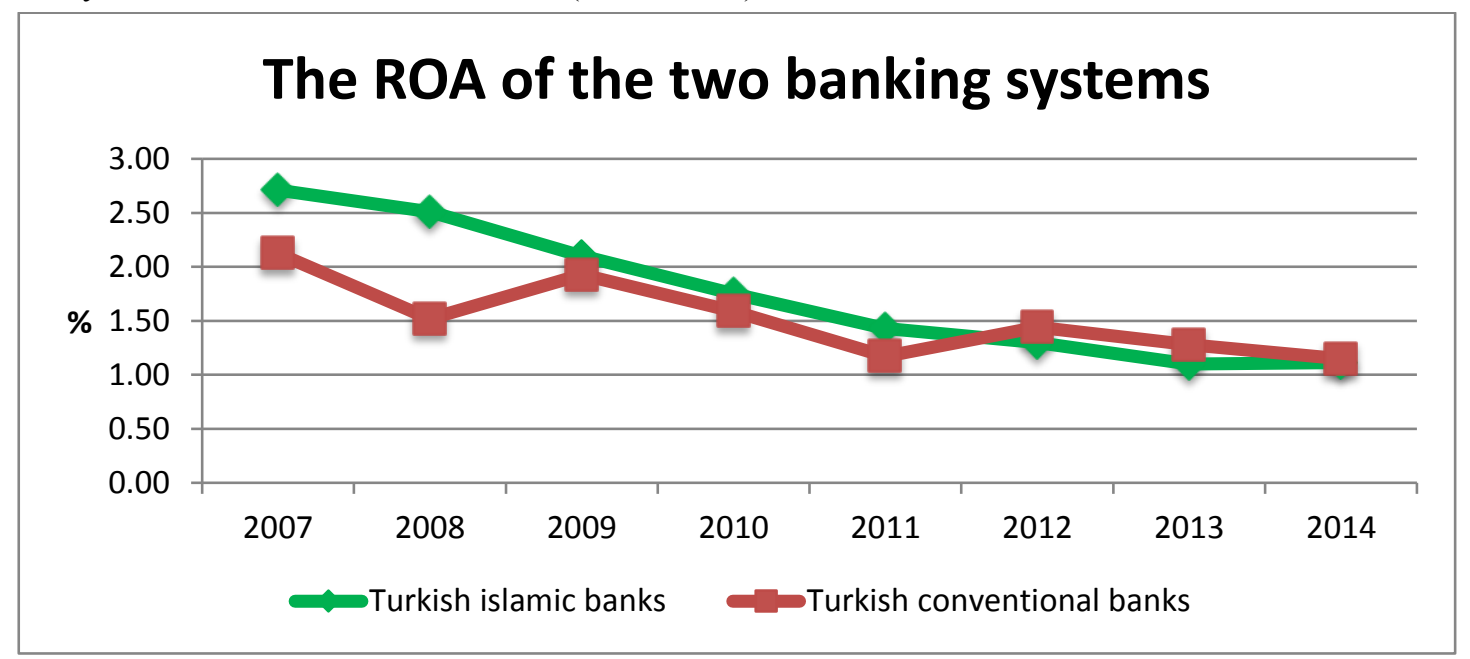

Figure 2: ROA of the Two Banking Systems Source: Own Calculation Based on the Annual Reports of the Banks 
The conventional banks reached lower ROA ratios than the Islamic ones until 2012. The fluctuation of the conventional banks let us think that there is a bigger instability in the conventional banks. The diagram shows a continuous decrease in the Islamic banks but we see more stable picture. Both sector reached the healthy limit.

Finally we have to approve our first hypothesis: the profitability of Islamic banks were better than the profitability of conventional banks during the crisis.

\subsection{The Analysis of Liquidity}

Liquidity means how quickly a bank can convert its assets into cash at face value to meet the cash demands of the depositors and borrowers. It is important to examine the liquidity because the banks had to face with liquidity problems during the crisis. We use the IAR ratio, which indicates what percentages of the assets of the bank are tied up in loans (Mosab, 2014).

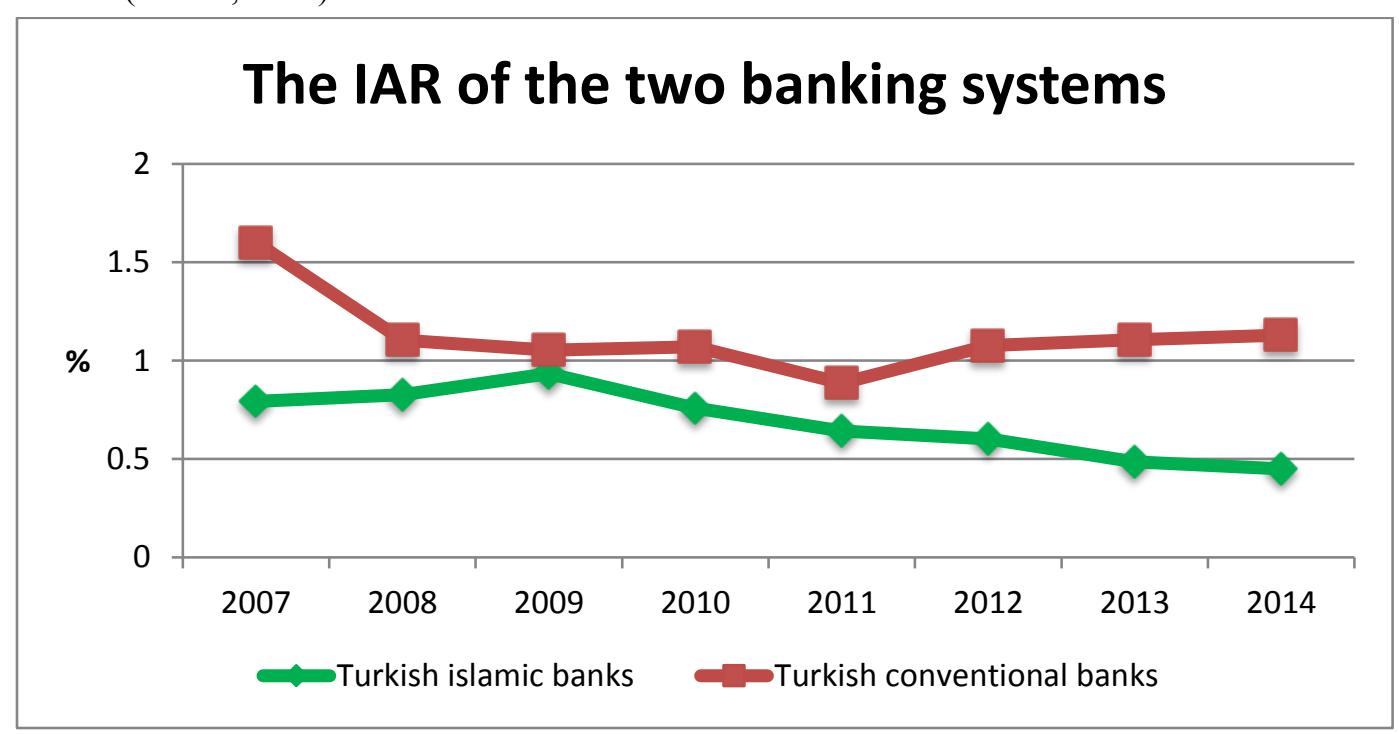

Figure 3: The IAR of the Two Banking Systems Source: Own Calculation Based on the Annual Reports of the Banks

The lower the IAR is the more liquid the bank is. The diagram shows that Islamic banks were in better situation even if they almost reached the level of the conventional banks in 2009. From 2007 to 2009 the IAR ratio of the Islamic banks increased by $0,17 \%$, the reason for it could be the difficulties of the crisis while the ratio of the conventional banks decreased by $0,48 \%$. We can find a reason for it: the investments of the conventional banks decreased while the investments of the Islamic banks increased.

In summary, we can state our second hypothesis has been approved: the liquidity of the Islamic banks were higher than conventional ones during the crisis.

\subsection{The Analysis of Leverage}

A leverage ratio is meant to evaluate a company's debt levels, it shows the proportion of own liabilities and nonown liabilities. If the leverage ratio is too high, then the bank operates with high risk. Low leverage ratio is not good either as it can cause decrease in the profitability (Baka et al, 2012).

\section{The Leverage ratio of the two banking systems}

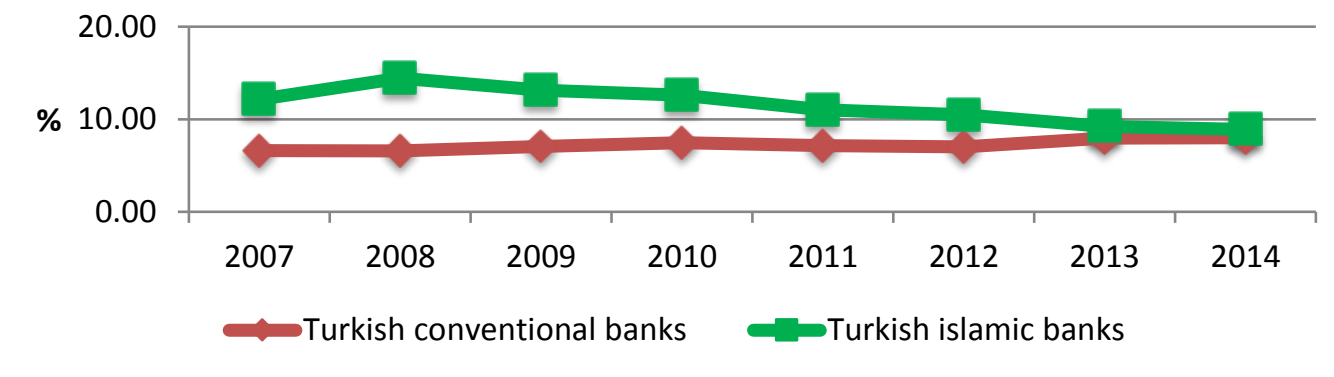

Figure 4: The Leverage Ratio of the Two Banking Systems Source: Own Calculation Based on the Annual Reports of the Banks 
The diagram shows that the Islamic banks have a much higher leverage than the conventional banks in every year. The highest percentage was in 2008 , with the value of $14,44 \%$. It means the equity is $14,44 \%$ of the non-own liabilities. We can see a continuous decrease from 2008, till there is an increase from 2008 in the conventional banks. The high leverage during the crisis let us think, the crisis had not forced Islamic banks decrease their risk taking. So our third hypothesis is proved.

\section{Summary}

Till the crisis in 2008 the conventional banks suffered from crisis of confidence, so the customers started to turn to alternative financial techniques like Islamic banking.

The best-known specialty of Islamic banks is the prohibition of interests. The Islamic banks can only finance real economical transactions, are based on profit and loss sharing, speculative ones are prohibited.

The aim of our study is proving that Islamic banks are more crisis-resistant than the conventional banks. We compared four Islamic banks with four conventional banks in Turkey. We focused on profitability, liquidity and leverage of the banks. We had three hypotheses, all of them were proved by our examination.

Turkey has been less affected by the financial crisis than other developed countries, so there was less decreases in the ratios of Turkish bank system. Furthermore the Turkish Islamic sector reached better results than the Turkish conventional sector.

If Islamic banking sector could cope with the prejudices, there would be bright future for the sector. Some further research field could be to examine a country shocked by the crises more, to get more detailed picture about the crisis-resistance of Islamic and conventional banks.

\section{References}

- Baka I.-Dancsó J.-Ligeti S.-Szarvas F.-Vágyi F.-Varga J.2012: Banking, Budapest

- Balázs J. 2008: „Economy-Venture-Competitiveness in the Islamic communities” Budapest-Sopron-Kairó, p. 5-9.

- Falus O. 2014: „A moral tax-The zakat”, Taylor Gazdálkodás- és szervezéstudományi folyóirat, p. 64-69

- Mosab I. T-Raj S. D. 2014: „The Impact of Global Financial Crisis on the Stability of Islamic Banks: An Empirical Evidence", Journal of Islamic Banking and Finance, p. 377-380

- Pálfi G. 2010: „Islamic finance in the finance markets”, Fordulat, 11

- Tálos L. 2015: „, The analysis of the influence on Turkish Islamic banks of the economic crisis by CAMEL method"p. 10-59

- Varga J. 2013: „The analysis of the balance sheet of the Islamic bank”, ASS Acta Scientiarum Sociolanum, 41

- Yousefi V. - Kóbori J. 2013: „The history of money and bank system of the Islamic world”, Valóság, 56,p. $30-46$

- http://www.ey.com/Publication/vwLUAssets/World_Islamic_Banking_Competitiveness_Report_201314/\$FI LE/World\%20Islamic\%20Banking\%20Competitiveness\%20Report\%202013-14.pdf

- Ceki Bildem: Islamic bankink in Turkey: A safe heaven for investors?, 2014 http://herdem.av.tr/islamicbanking-turkey-safe-haven-investors/

- $\quad$ Turkey Islamic Finance Report 2014

- http://www.irti.org/English/Research/Documents/Report-5.pdf 